\title{
Development of Higher Order Thinking Skill in Junior High School: Studies on Social Studies Teachers in Pekalongan City
}

\author{
Arif Purnomo ${ }^{1, *}$ Ferani Mulianingsih ${ }^{2}$
}

\author{
1,2 Universitas Negeri Semarang \\ *Corresponding author. Email: arifpurnomo32@mail.unnes.ac.id
}

\begin{abstract}
The objective of this research is to explain the ability of teachers to develop high-level questions (HOTS) and its relationship with students' critical thinking skills. The research informants were social studies teachers in Pekalongan City. The conclusions of the study are developing higher order thinking skills has an impact on students' skills in critical thinking. Learning development in this way has a dependence on teacher factors. The teacher is the main factor that can improve critical thinking skills.
\end{abstract}

Keywords: Higher order thinking skill, junior high school, social studies, teachers.

\section{INTRODUCTION}

One of the basic competencies of teaching teachers is the ability to develop questions. In the learning practice, the teacher poses a variety of questions to students, ranging from low-level questions to high-level questions. However, from various studies, it turns out that questions in the low-level category are very frequent. The questions posed by the teacher are questions that simply ask students to recall information that has been read or heard in class discussions. These questions do not involve higher order mental operations such as application, synthesis, interpretation, and understanding of cause and effect [1]. In fact, in class, higher order thinking skills (HOTS) are something that must be presented in every lesson.

High level questions was aimed, among others, to encourage or trigger students' mental operations that are very well suited to the learning format for problem solving and discovery. Questions that can be asked are "how..." "why...", "how do we know...", "show that..." or "if that is true, then..." [2].

Teacher competence in developing high-level questions is needed for the development of students' critical and analytical thinking skills. Almost no one doubts that students' critical thinking can be influenced by teacher learning and question development. Having the ability to think critically in students will be useful in developing the ability to make decisions to solve problems [3]. Therefore, students must be familiarized with questions and learning oriented towards higher order thinking skills in order to encourage their critical thinking skills.

Last decade, critical thinking has become a very popular term for social studies learning. It is stated that social studies learning has a contribution to the development of students' thinking abilities [4] [5] [6]. In fact, several writings have examined the relationship between critical thinking as part of learning that must be trained in students [7] [8] [9] [10].

Social studies has great potential in developing students' critical thinking skills, considering that the object of study of this subject revolves around human life and its relationship with the surrounding environment. Critical thinking in social studies means providing space for students to be able to verify information and make contextual analysis of what is learned in class.

Unfortunately, social studies learning so far has not placed critical thinking skills as a unit of student cognitive development [11]. Learning is often responded less actively, because teachers still use a monologue perspective rather than dialogue [12]. Monologous learning closes the possibility of efforts to cultivate critical power and shackle students to any information given [13]. The lack of dialogue in the classroom has made social studies learning, which 
should be oriented towards developing knowledge towards social practice, has stopped at mere theoretical aspects. Whereas the dialogical method through discussion can make students able to accept other people's opinions, be tolerant, and express opinions well, politely and clearly [14].

The dominant factor that causes obstruction to the process of forming students' critical thinking skills is the ability of teachers in learning, especially their competence in developing high-level questions. This is in line with Chen et al's opinion which states that the teachers' role in process of forming students' critical knowledge is influenced by their competence [15]. Therefore, this paper not only discusses the ability of teachers to develop high-level questions, but relates them to teachers' understanding of the concept of social studies learning.

\section{METHODS}

The study used phenomenological studies in qualitative research [16]. The focus of the study was on the ability of social studies teachers to develop highlevel questions. The focus of the research was SMP in Pekalongan City, namely SMP N 1, SMP N 3, SMP N 7, SMP N 8, and SMP N 13. The data was collected using observations. interviews, and document analysis. The implementation of checking the validity of the data was based on four criteria, namely the degree of trust, transferability, dependence, and certainty. Data analysis activities in this study refer to Creswell's phenomenological data analysis framework.

\section{RESULTS AND DISCUSSION}

\subsection{Social Studies Learning and the Ability to Train Students' High-level Thinking}

The teacher's understanding of the social studies learning objectives is stated in the following sentence. "It is hoped that students will be able to recognize concepts related to community life and their environment. Having the basic ability to think logically and critically, curiosity, inquiry, problem solving, and skills in social life "[17]. The Head of Pekalongan City Social Studies Teacher Deliberation (MGMP) also stated that "the goal of social studies learning is to develop the potential of students to be sensitive to personal problems, social problems that occur in society, to have a positive mental attitude towards correcting any imbalances that occur, and be skilled. overcome every problem that occurs everyday in the family environment and society. " [18].

It seems that the understanding of the concept of social studies learning by teachers is based on the idea that social studies has three major traditions, namely: social studies as citizenship transmission, social studies as reflective inquiry, and social studies as social science [19]. This understanding is indeed a common understanding among social studies educators in Indonesia.

Understanding of social studies learning is manifested in the implementation of learning which begins with designing a lesson plan. In social studies learning planning, teachers understand the importance of including 4C elements (Communication, Collaboration, Critical Thinking and Problem Solving, and Creativity and Innovation) as skills developed in 21 st century learning. This $4 \mathrm{C}$ aspect is translated into the implementation of step-by-step learning to see the extent of the teacher's applicable understanding of the concept [20].

In fact, the teacher does not translate the $4 \mathrm{C}$ concept, but the teacher fills in the $4 \mathrm{C}$ column with activities that are not contextual with the applicable guidelines. For example, in the aspects of critical thinking and problem solving, the teacher fills in with question and answer activities. The question and answer activity in question is the post process the teacher explains the material. Question and answer activity in learning is a must, because from it the dialectic and knowledge discovery process will be born. Another uncontextual condition in the lesson plan is that the teacher does not explain the approach they use to carry out learning, even some teachers fill in the approach column with an integrated concept.

In the practice of implementing social studies learning, the ability to develop students' higher order thinking skills is strongly influenced by the teacher's ability to add to the latest knowledge and his ability to analyze material. Mastery of contemporary knowledge is also influenced by the literacy of social studies teachers. The literacy competence of a teacher greatly influences the understanding that will be formed in learning [21]. Literacy is meant as an encouragement to continue learning from a variety of sources. Teachers with high literacy will easily explain material in a popular and easy-to-understand framework, in contrast to teachers who do not have the motivation to learn. They will explain the material statically and difficult to understand. The use of contemporary issues is actually a stimulus for teachers to make social studies learning more contextual. But unfortunately, in the observations made, the teacher still has difficulty explaining the material related to the current situation. For example, regarding poverty, teachers only explain poverty in a theoretical understanding, even though the learning resources about poverty are quite numerous and complex in digital form.

The teacher's ability to analyze material and develop evaluation tools is also an important factor in shaping the critical thinking skills of the students. Unfortunately, in the practice of social studies learning, "most of the 
social studies evaluation tools are still monotonous and less varied, usually only multiple choice and essays. The levels tend to just memorize, and do not invite students to think at higher levels. [22].

Giroux [23] argues that education with a critical paradigm must pay attention to the position of teachers and students in the classroom. The best approach is one that focuses on student learning, this reason is chosen based on experience. In an era of openness like now, it is not impossible that students can be more advanced than a teacher in terms of knowledge. Therefore the teacher must start to realize this. Focusing learning on students is one of the best ways to accumulate all forms of knowledge that students have.

In learning practices, there are teachers who rarely practice students' critical thinking skills by developing high-order questioning skills. The reasons put forward were the large number of social studies material factors, familiarity with the usual tendencies of learning, difficulty in designing questions at a high level of thinking, and the age before retirement. However, not all teachers are like that. There are teachers who try to develop their own competencies to develop learning oriented towards developing higher order thinking skills. In this group are teachers who often attend training and the average teacher is in the young category.

\subsection{High Level Thinking Ability and Critical Thinking in Social Studies Learning}

In developing higher order thinking skills, teacherdeveloped learning must be oriented towards dialogical learning that aims to encourage students' abilities to investigate and articulate their own experiences. In this rationality, teachers and students are dialogically encouraged to understand hidden realities that are not planned, programmed and unwritten, but which also influence the educational process, which is what is known as the hidden curriculum. This was done by the teacher to minimize the impression that "Social studies is only a subject that requires memorization" [24].

In this context, teachers need to develop dialogical learning and apply the HOTS model assessment, both in assignments and in the final test. HOTS is proven to be able to stimulate the growth of students' knowledge. Through the application of HOTS, the development of critical social studies knowledge will run well. The results of this study support the opinion of Hess

Byford and Russel [26], and Dilworth [27] that the formation of critical student understanding and through student active participation, democratic citizenship learning will occur. So that students will be equipped with the ability to argue, argue, accept, and if necessary criticize a situation in order to find a solution. Thus, social studies learning will be contextual, rooted, and become a golden bridge in efforts to form citizens who have an awareness of their rights and obligations and are able to be directly involved in social life.

Teachers who develop higher order thinking skills in their learning can develop students' critical thinking skills. Ahmad Aziz developed one of the following items.

1. Perhatikan grafik berikut!

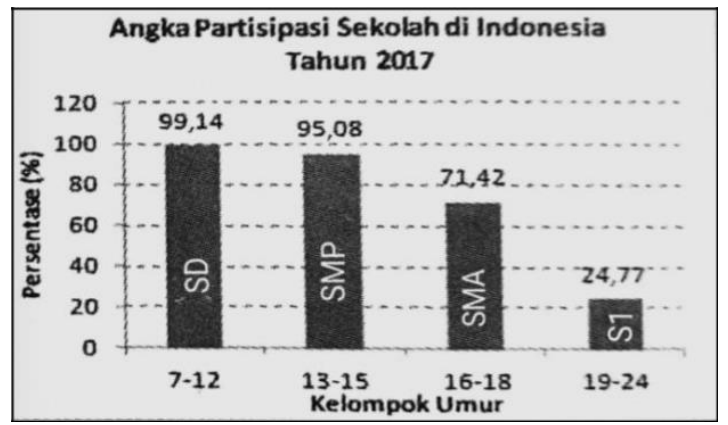

\section{Sumber : Badan Pusat Statistik, 2018}

Berdasarkan grafik tersebut, fakta yang dapat disimpulkan adalah....

A. angka partisipasi sekolah SMP lebih tinggi dibandingkan SMA tetapi lebih rendah dari usia SD

B. angka partisipasi sekolah pada tingkat SMA paling rendah jika dibandingkan dengan $\mathrm{S} 1$

C. penduduk bertingkat pendidikan Strata 1/Diploma masih rendah jika dibandingkan dengan keseluruhan jumlah penduduk

D. angka partisipasi penduduk di tingkat Sekolah Dasar (SD) rendah jika dibandingkan dengan seluruh tingkatan

Key: C

The sample questions developed by Ahmad Aziz gave rise to critical attitudes of students. Students are required to analyze a stimulus in the form of a graphic.

Indeed, one of the tips for compiling HOTS questions is through disclosing cases that come from everyday life. Students are asked to review the data in graphs and tables, by relating the problem to the concepts and knowledge they have received.

Various responses arise from students to the questions developed by the teacher. Some stated that the questions were not in the book, not in accordance with the material being taught, the questions made by the teacher were difficult questions. A small number consider that the questions developed are "challenging" questions and train thinking skills. This group seems to be able to develop their critical thinking skills. Terefore, the impact of the learning he does is that students become analytical and critical. 


\section{CONCLUSION}

Social studies learning that is directed at developing higher order thinking skills has an impact on students' skills in critical thinking. Learning development in this way has a dependence on teacher factors. The teacher is the main factor that can improve critical thinking skills.

There are teachers who are at the liminal stage where they consider that the development of HOTS questions is still only a hope. On the other hand, there are teachers who are at the post liminal stage who think that the development of questions is a must.

\section{AUTHORS' CONTRIBUTIONS}

This paper provides an understanding of the tendency of teachers in developing social studies questions. There is a stage where the teacher feels comfortable with his position so far by assuming that the development of HOTS questions is still a hope. But on the other hand, there are groups of teachers who have been freed from the liminal stage, to the post liminal stage, when they have succeeded in developing it and consider that it has become a necessity

\section{ACKNOWLEDGMENTS}

The author thanks the informants who have provided information about the real conditions of social studies learning in the classroom. Appreciation also conveyed to the Dean of the Faculty of Social Sciences, Universitas Negeri Semarang, who has provided financial support so that this article can be published.

\section{REFERENCES}

[1] Azis Wahab, Moh. Metode dan Model-model Mengajar, pp. 107. Alfabeta, Bandung, 2007.

[2] Azis Wahab, Moh. Metode dan Model-model Mengajar, pp. 107. Alfabeta, Bandung, 2007.

[3] Widodo, Sigit. "Pengembangan Keterampilan Berpikir Kritis Peserta Didik dengan Menggunakan Model Pembelajaran Berbasis Masalah (Problem Based Learning) Melalui Isuisu Sosial Ekonomi Pasca Penggenangan Waduk Jatigede dalam Pembelajaran IPS di SMP N 2 Wado Kabupaten Sumedang Kelas VIII C", International Journal of Pedagogy of Social Studies, 1(2), pp. 1-14, 2016. DOI: https://doi.org/10.17509/ijposs.v1i2.4712

[4] Mc Peck, J.E.. Critical Thinking and Education. Martin Robertson, Oxford, 1981.

[5] Siegel, I. E. "A Constructivist Perspective for Teaching Thinking”. Educational Leadership, 42(3), pp.18-21, 1984.
[6] Karabulut, U, S. "How to Teach Critical Thinking in Social Studies Education, an Examination of Three NCSS Journals". Eurasian Journal of Educational Research, 49, pp.197-214, 2012. from https://www.learntechlib.org/p/159871

[7] Onosko, J. J. "Barriers to the Promotion of Higher-Order Thinking in Social Studies". Theory \& Research in Social Education, 19(4), pp. 341-366, (1991). https://doi.org/10.1080/00933104.1991.105 05646

[8] Olsen, D. "Less" can be "More" in The Promotion of Thinking". Social Education, 59(3), pp. 130-134, 1995.

[9] Wright, I. "Critical Thinking in Social Studies: Beliefs, Commitments, and Implementation". Canadian Social Studies, 29(2), pp. 66-68, 1995.

[10] Willen, W. and Philips, J. "Teaching Critical Thinking: A Metacognitive Approach". Social Education, 59(3), pp. 135-138, 1995.

[11] Adler, S. "18. The Education of Social Studies Teachers". Handbook of Research in Social Studies Education. California: Sage Publications, pp. 329-351, 2008.

[12] Leming, J. S. "Some Critical Thoughts about the Teaching of Critical Thinking". The Social Studies, 89(2), pp. 61-66, 1998.

[13] Barr, R. D., Barth, J. L \& Shermis, S. S. Defining the Social Studies. Wahington: National Council for the Social Studies Washington, DC, 1977.

[14] Suyahmo, S. dan Moh. Aris Munandar. "Solusi Permasalahan Proses Demokrasi di Indonesia Modern melalui Peningkatan Kemampuan Musyawarah Sejak Dini”. Integralistik, 28(2), pp.202-216, 2017.

[15] Chen, H., De, P., Hu, Y. J., \& Hwang, B.H. "Wisdom of Crowds: The Value of Stock Opinions Transmitted Through Social Media". The Review of Financial Studies, 27(5), 1367-1403, 2014.

[16] Creswell, J. W., \& Creswell, J. D. Research Design: Qualitative, Quantitative, and Mixed Methods Approaches. Sage Publications, New York, 2017.

[17] Wawancara dengan Surani, tanggal 28 Januari 2021. 
[18] Wawancara dengan Casyono, tanggal 29 Jnuari 2021.

[19] Dharma, S., \& Siregar, R. "Internalisasi Karakter melalui Model Project Citizen pada Pembelajaran Pendidikan Pancasila dan Kewarganegaraan". JUPIIS: Jurnal Pendidikan Ilmu-Ilmu Sosial 6 (2) 132-137, 2014, https:// DOI:10.24114/ jupiis.v6i2.2293

[20] Barr, R. D., Barth, J. L \& Shermis, S. S. Defining the Social Studies. Wahington: National Council for the Social Studies Washington, DC, 1977.

[21] Malikow, M. "Engaging Students in Controversial Issues". Kappa Delta Pi Record, 42(3), pp.106-108, 2006.

[22] Wawancara dengan Karyono, tanggal 28 Januari 2021.

[23] Giroux, H. A. On Critical Pedagogy. Bloomsbury Publishing, New York, 2000.

[24] Wawancara dengan Wiwik Suryaningsih, tanggal 29 Januari 2021

[25] Hess, D. E. "Controversial Issues And Democratic Discourse". Handbook of Research in Social Studies Education, 124136.2008 .

[26] Byford, J., Lennon, S., \& Russell, W. B. "Teaching Controversial Issues in the Social Studies: A Research Study of High School Teachers". The Clearing House: A Journal of Educational Strategies, Issues and Ideas, 82(4), pp. 165-170, 2009. https://doi.org/10.3200/TCHS.82.4.165-170

[27] Dilworth, P. P. "Multicultural Citizenship Education: Case Studies From Social Studies Classrooms". Theory \& Research in Social Education, 32(2), pp. 153-186, 2004. 